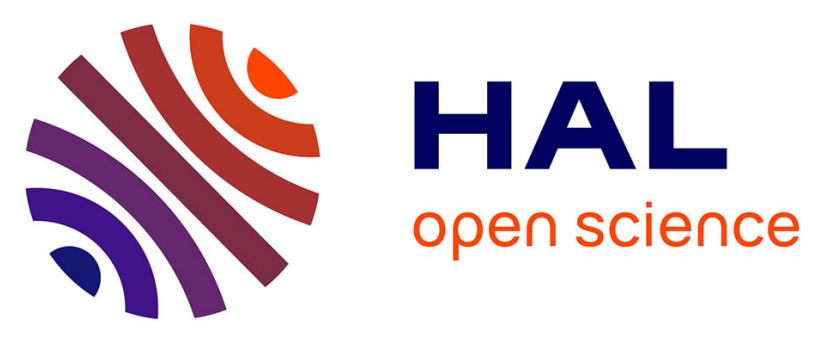

\title{
Ecosystem-based adaptation
}

Bruno Locatelli, Emilia Pramova

\section{To cite this version:}

Bruno Locatelli, Emilia Pramova. Ecosystem-based adaptation: In: SWAMP toolbox: Theme B section B1.. École thématique. Indonesia. 2015. cel-01116258

\section{HAL Id: cel-01116258 \\ http://hal.cirad.fr/cel-01116258}

Submitted on 12 Feb 2015

HAL is a multi-disciplinary open access archive for the deposit and dissemination of scientific research documents, whether they are published or not. The documents may come from teaching and research institutions in France or abroad, or from public or private research centers.
L'archive ouverte pluridisciplinaire HAL, est destinée au dépôt et à la diffusion de documents scientifiques de niveau recherche, publiés ou non, émanant des établissements d'enseignement et de recherche français ou étrangers, des laboratoires publics ou privés. 




\section{Topic B1. Ecosystem-based adaptation}

Bruno Locatelli and Emilia Pramova

$$
\text { 웅 USAID Peror }
$$




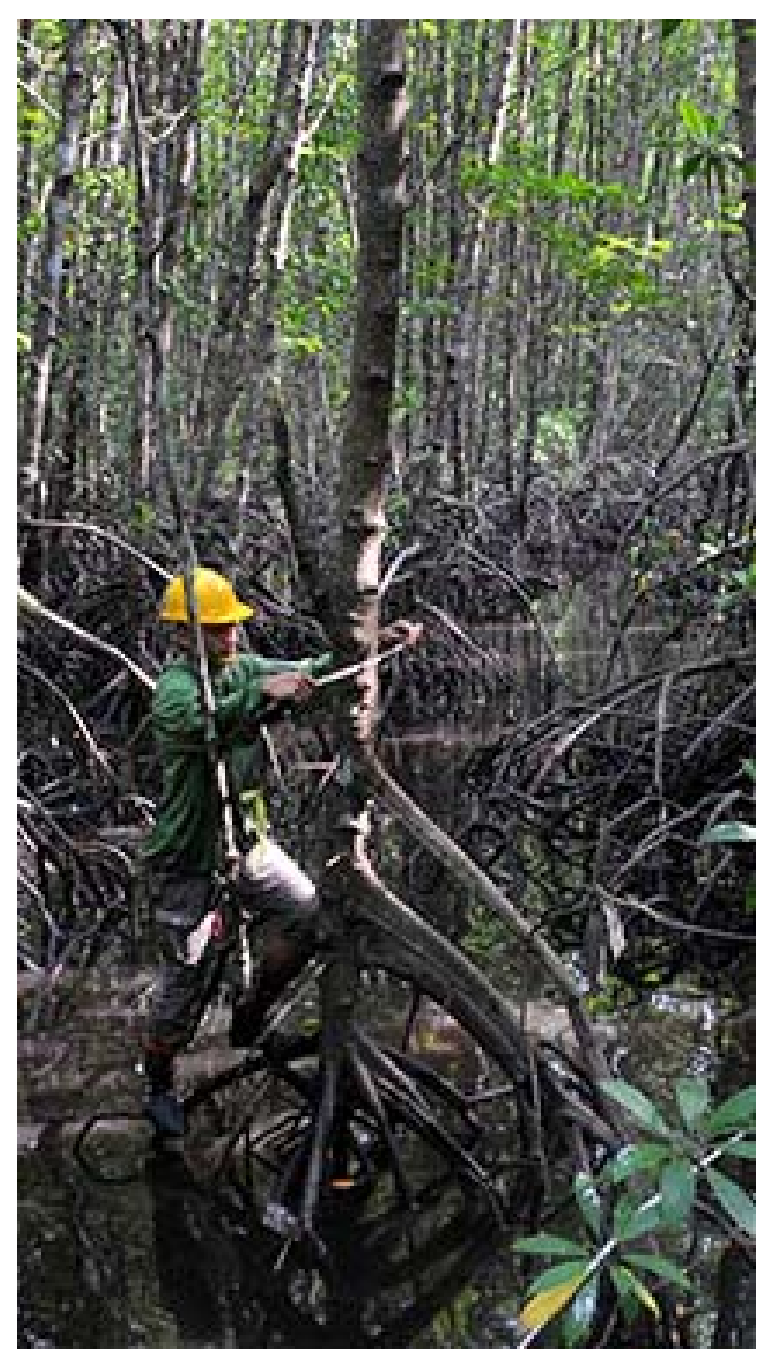

\section{I ntroduction}

- Ecosystem-based adaptation (EBA)

- "The use of biodiversity and ecosystem services as part of an overall adaptation strategy to help people to adapt to the adverse effects of climate change." (CBD 2009)

- "Adaptation policies and measures that take into account the role of ecosystem services in reducing the vulnerability of society to climate change" (Vignola et al. 2009)

- "Local and landscape scale strategies that enable both people and nature to adapt in the face of climate change" (IUCN 2009)

- EBA is human-centered 


\section{EBA framework}

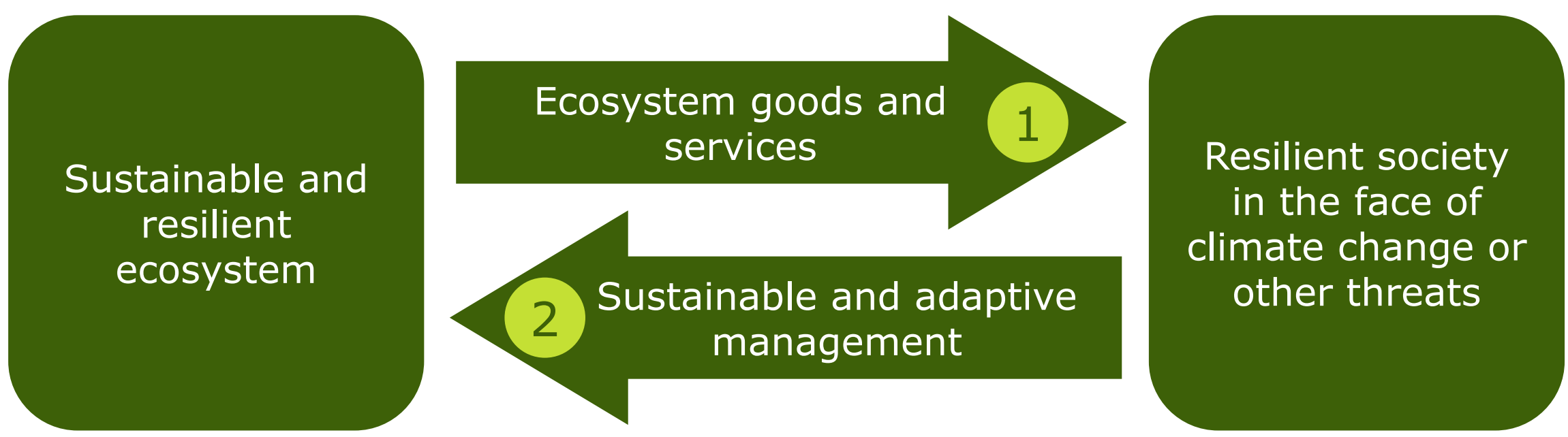

1 Ecosystems for the adaptation of society to climate variations

2 Sustainable management of ecosystems for sustainable provision of services

+ Adaptation of ecosystems to climate change (if sustainable management is in place and human drivers of degradation are under control) 


\section{EBA actors}

- The term "EBA" is mainly used by:

- international NGOs and their projects

IUCN Ecosystem-based adaptation and lessons from the field

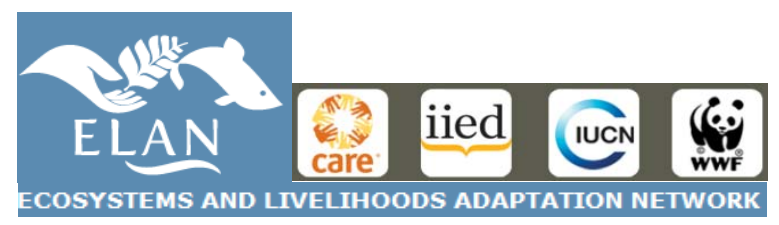

- international conventions (CBD, UNFCC) and their parties

- UNFCCC (2008): Submissions from countries

- (e.g. Colombia, Sri Lanka) or groups of countries

- (e.g. the African Group)

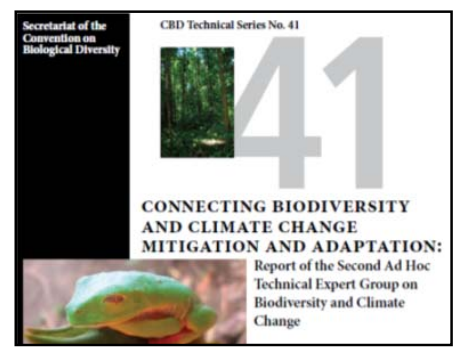

- What about:

- national policymakers?

- National Adaptation Programs of Action

- (NAPAs)

- scientists? 


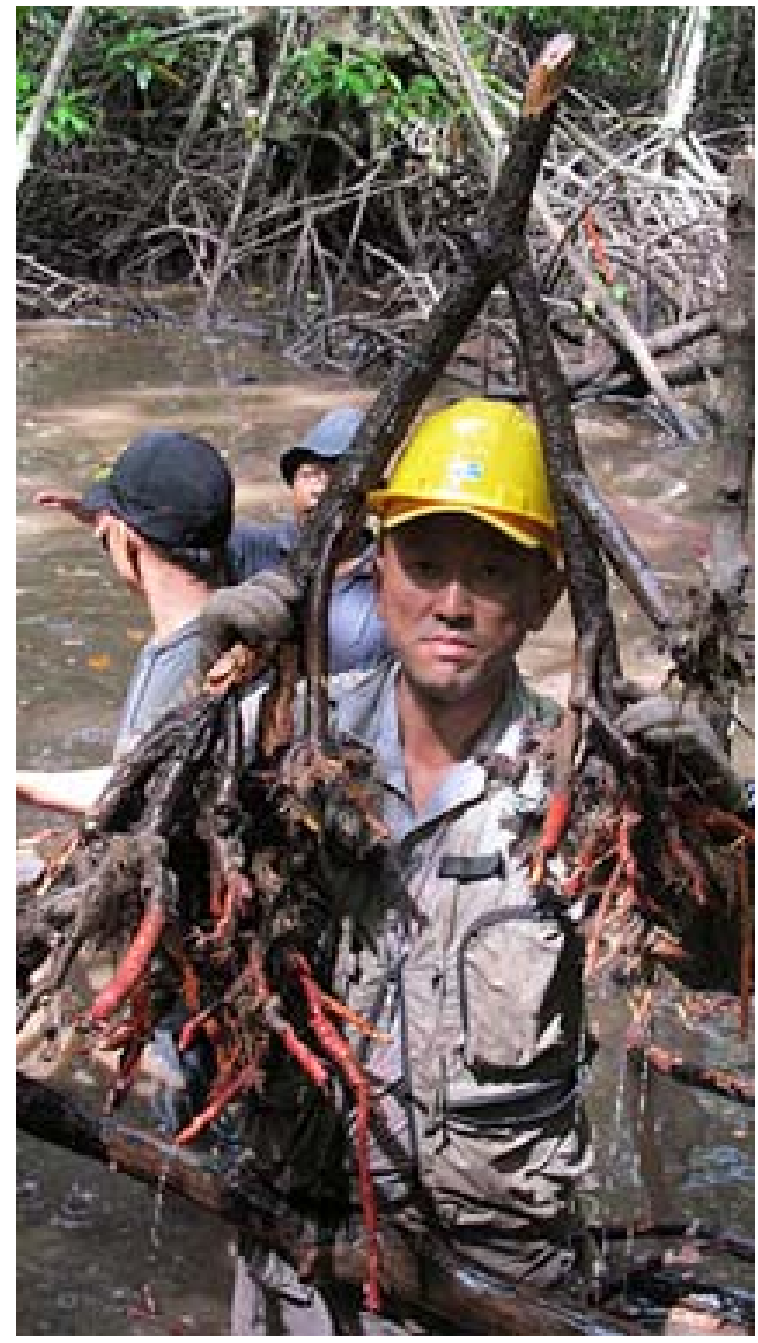

\section{Objectives of this presentation}

- Present the scientific evidence on EBA

- Analysis of literature $(*)$ : Peer-reviewed papers on forests or trees and human vulnerability

- Six major stories emerged from the analysis

- Discuss the opportunities and challenges of EBA

- Adaptation policies

- Co-benefits

- Challenges

* (Pramova et al. 2012b) 


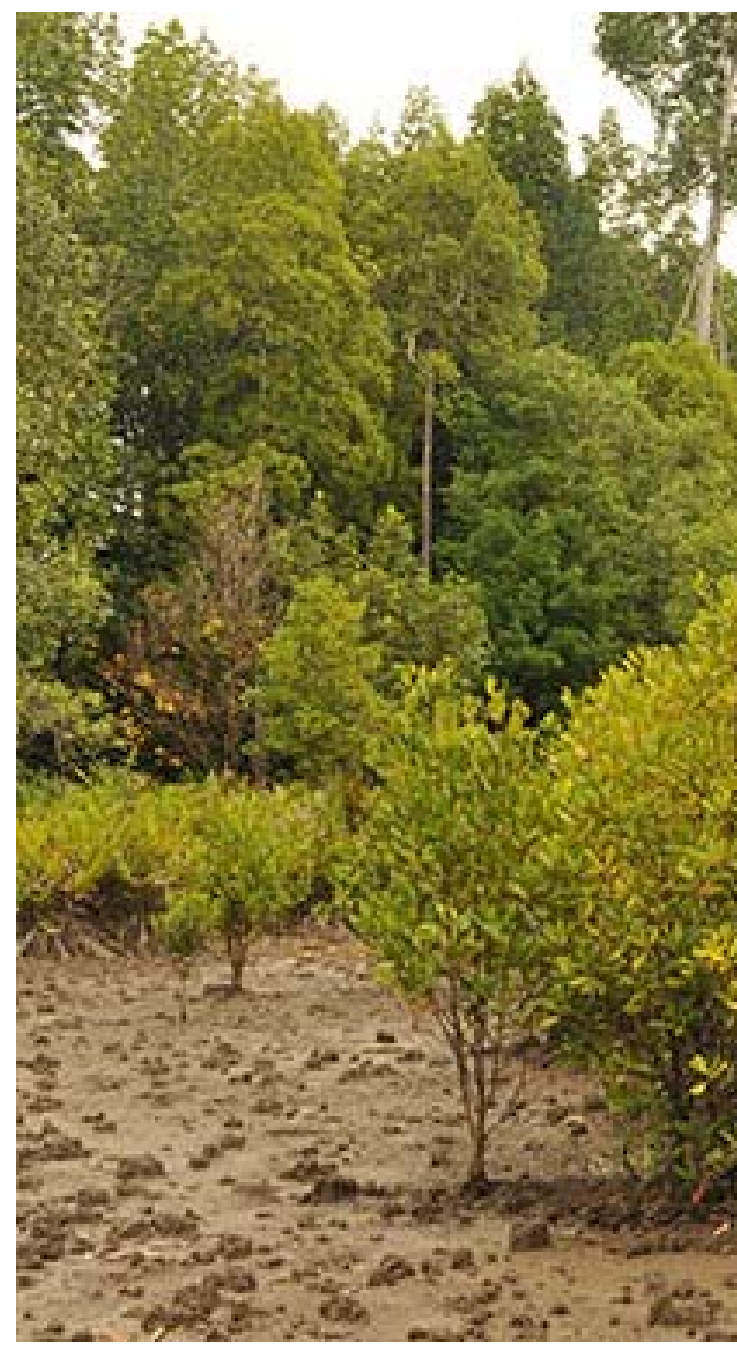

\section{Part 1. Presenting the scientific evidence on EBA}

- The question:

- What is the scientific evidence on EBA?

- The justification:

- We need this evidence to move EBA from concepts to action 


\section{Six major stories}

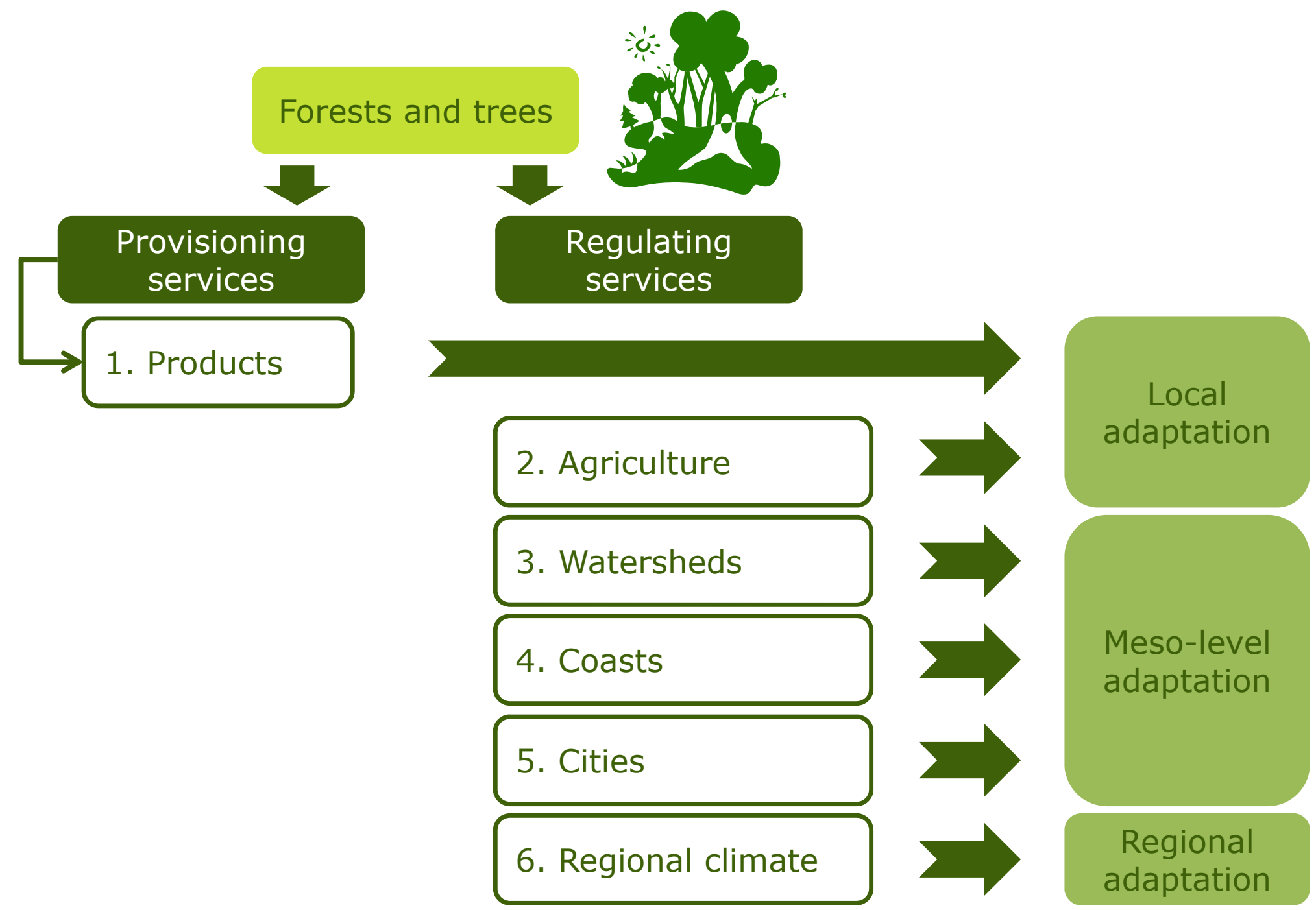




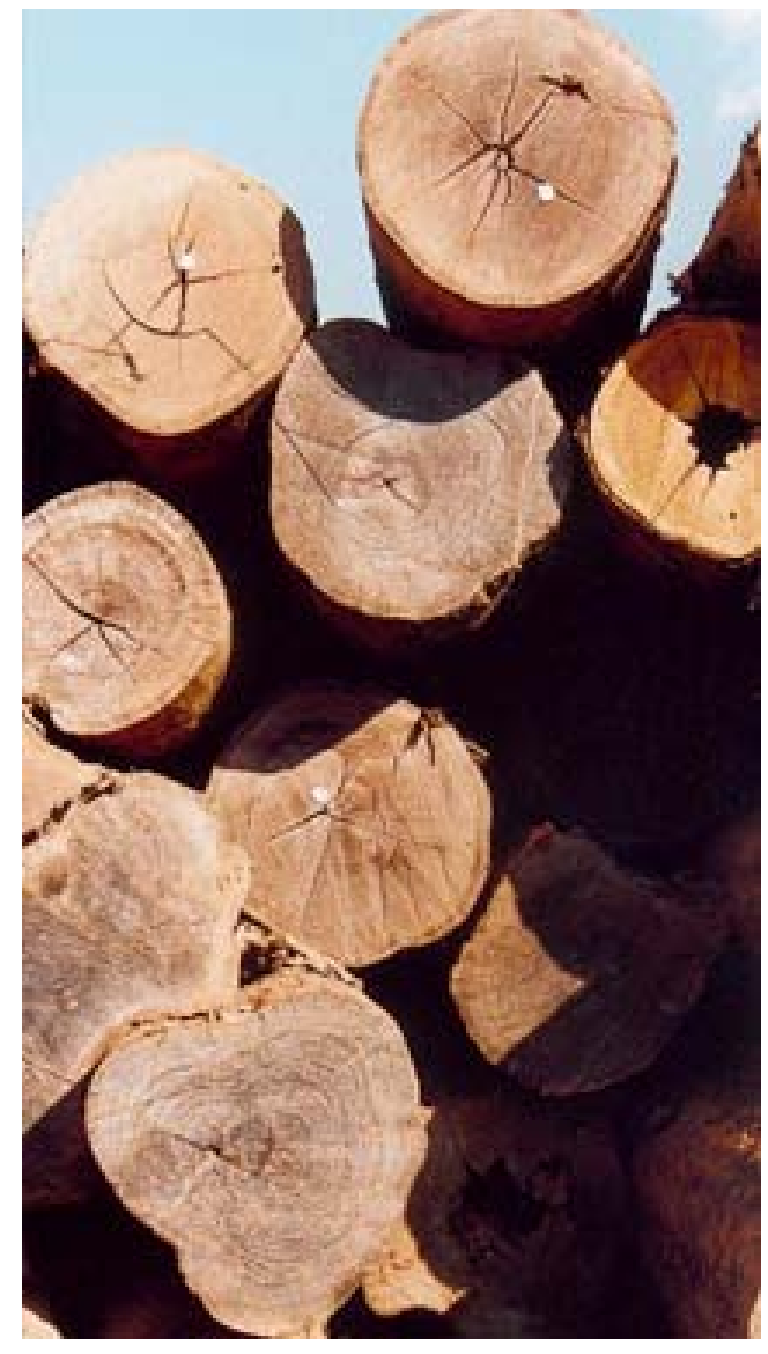

\section{Products}

- Forests and trees

- Provide safety nets for local communities coping with climate shocks

- Increase livelihood diversification (anticipatory strategy)

- Examples:

- Indonesia (Kalimantan) - the most heavily affected, the poorest and the least-educated relied more on forests for their coping strategies after a flood (Liswanti et al. 2011)

- Honduras - smallholders sold timber to recover from asset loss due to Hurricane Mitch (McSweeney 2005)

- Issues:

- Poverty trap? (out of the forest, out of vulnerability?)

- Sustainability of natural resources for adaptation

- Property rights and access 


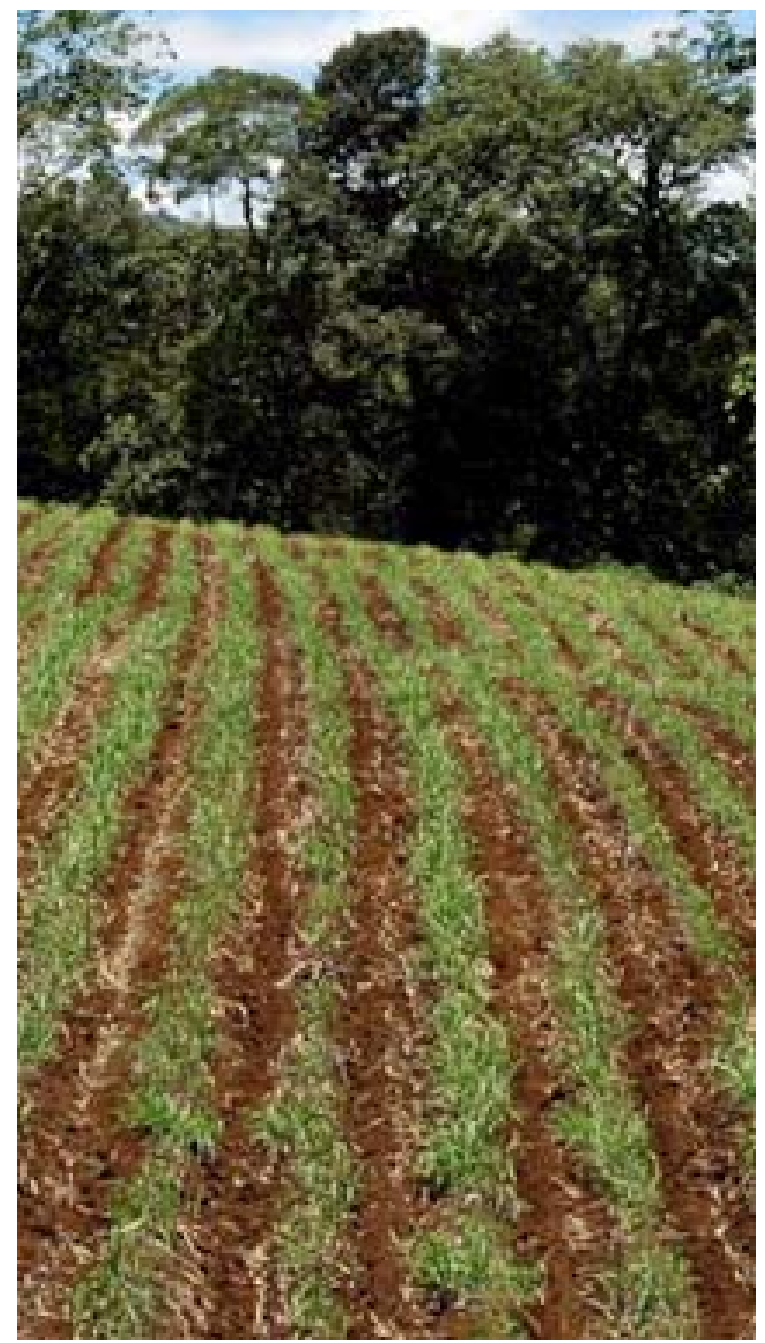

\section{Agriculture}

- Trees in agriculture

- Maintain production under climate variability and protect crops against extremes

- Local shade cover, soil fertility and moisture, wind breaks, water infiltration

- Examples:

- Indonesia (Sulawesi) - cacao systems shaded by Gliricidia trees were not significantly affected by drought because of shade and water uptake from the trees (Schwendenmann et al. 2010)

- Malawi - agroforestry using Faidherbia and Gliricidia showed modest grain yields during drought (Garrity et al. 2010)

- Issues:

- Trade-offs: Production vs. resilience 


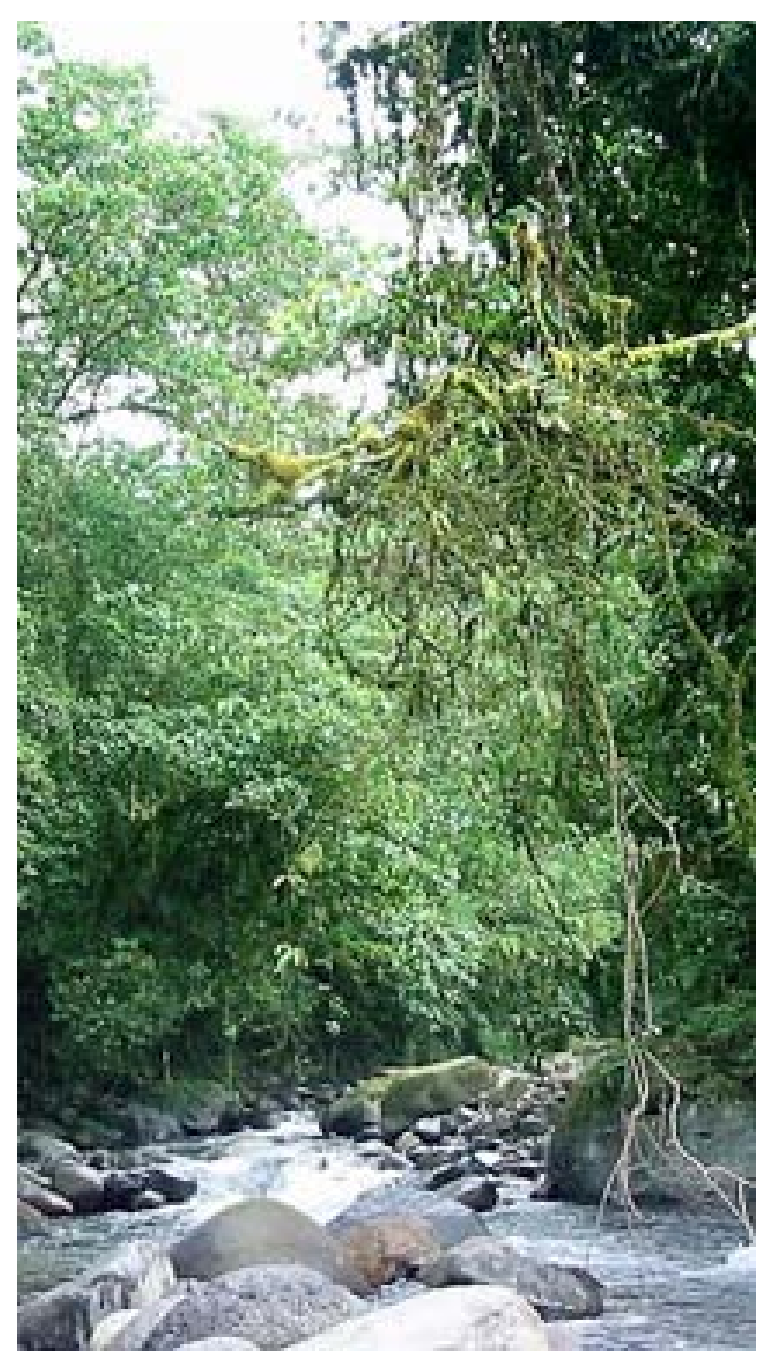

\section{Watersheds}

- Forests in watersheds:

- Regulate base flows (dry seasons), peak flows (intense rainfall), and stabilize soil (landslide risks)

- Examples:

- Indonesia (Flores) - Agrarian communities near forested watersheds in Flores showed lower impacts and higher profits during droughts (Pattanayak and Kramer 2001)

- Bolivia - reduction of landslide risks with forest plantations and regeneration (Robledo et al. 2004)

- Issues:

- Trade-offs between services (e.g. more regularity but less total water)

- Not enough evidence, many studies based on common wisdom, controversies (e.g. floods and forests) 


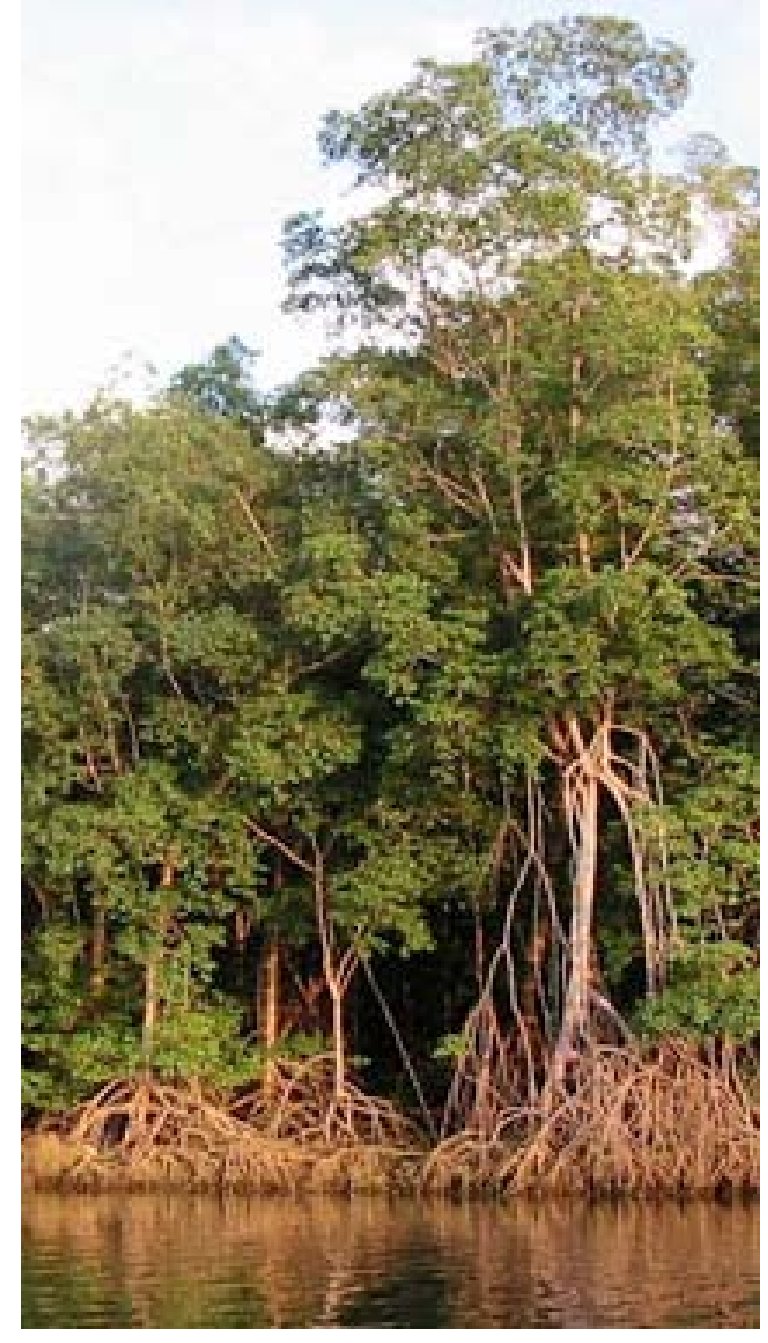

\section{Coasts}

- Coastal forests

- Absorb and dissipate wave energy and stabilize coastal land

- Protection from tropical storms, sea level rise, floods and coastal erosion

- Examples:

- India (Orissa) - Cyclone protection. Villages behind mangroves suffered less losses of life, property and crops during the 1999 cyclone (Badola and Hussain 2005)

- Vietnam - Reducing dyke maintenance costs. Benefits of US $\$ 70-130$ per ha/year (Tri et al. 1998; Das and Vincent, 2009)

- Issues

- What level of protection from extremes do they provide? 


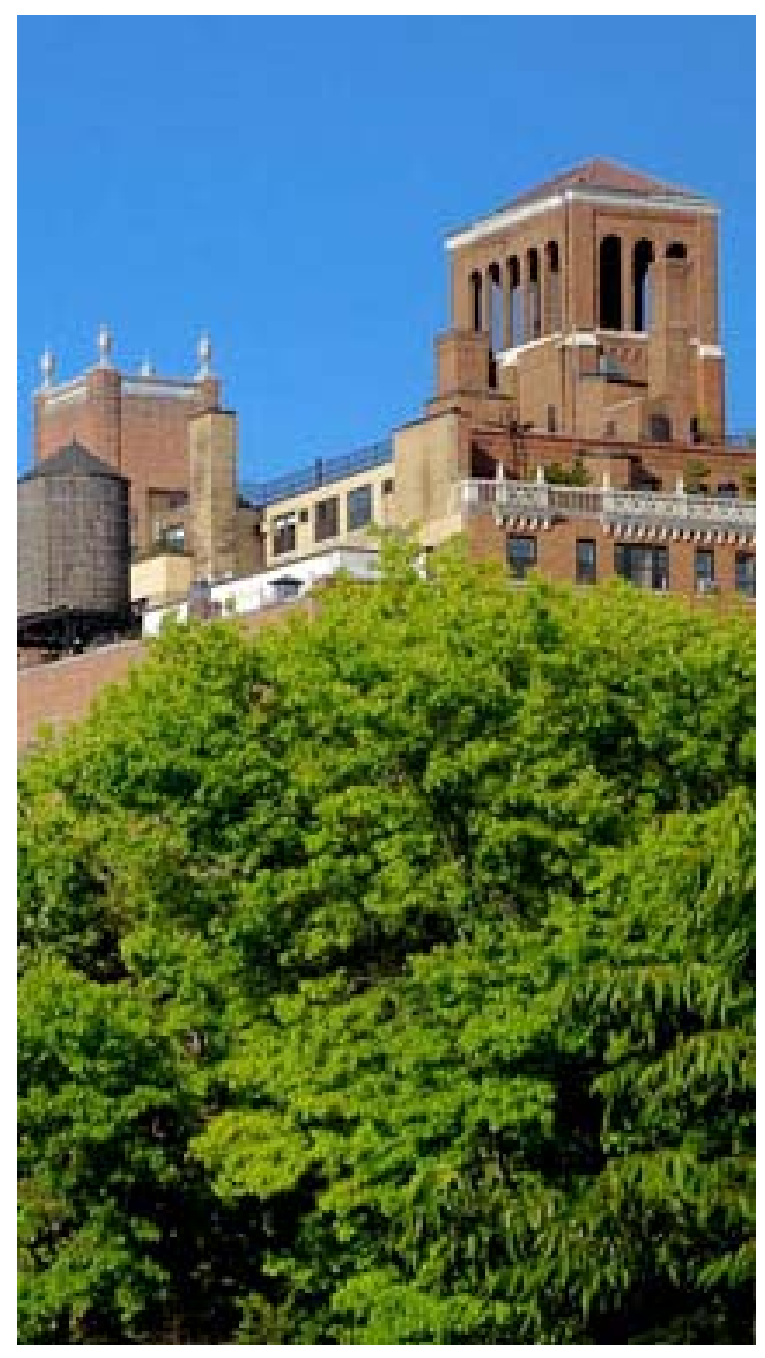

\section{Cities}

- Urban forests and trees

- Regulate temperature and water for resilient urban settlements

- Services: Shading, evaporative cooling, rainwater interception, storage and infiltration

- Examples

- Manchester (UK) - Reducing urban flood risk. Trees can reduce volume of surface runoff (by 5 to $6 \%$ ) (Gill et al. 2007)

- New Jersey (USA) - Reducing "urban heat island" effect and heat stress. Areas with mature canopies are $2.7-3.3^{\circ} \mathrm{C}$ cooler than areas without trees (Solecki et al. 2005)

- Issues

- Opportunity costs

- Studies almost only in developed countries 


\section{Regional climate}

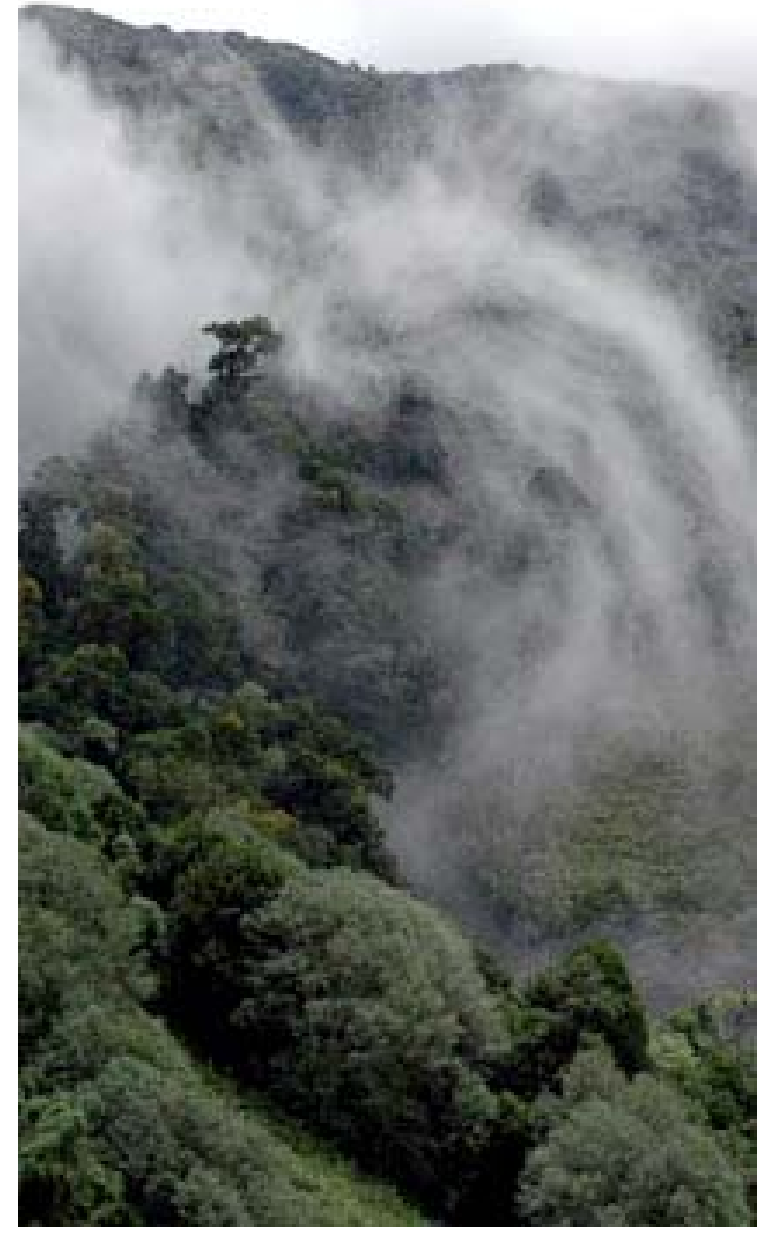

- Forests can influence regional climate:

- Cooling effect through increased evaporation and cloud cover

- Influence on precipitation: water pumping and rainfall recycling

- Examples:

- Amazon and West Africa - $40 \%$ of rainfall come from evapotranspiration over land (Ellison et al. 2012)

- Sahel - Biotic pump effect of forests, facilitating movements of water vapor from the Gulf of Guinea to the Sahel (Makarieva et al. 2007)

- Issues

- Controversies

- Multiple scales involved (local, regional, global)

- => How policies could address this role of forests? 


\section{Conclusions of part 1}

- Scales and evidence on EBA
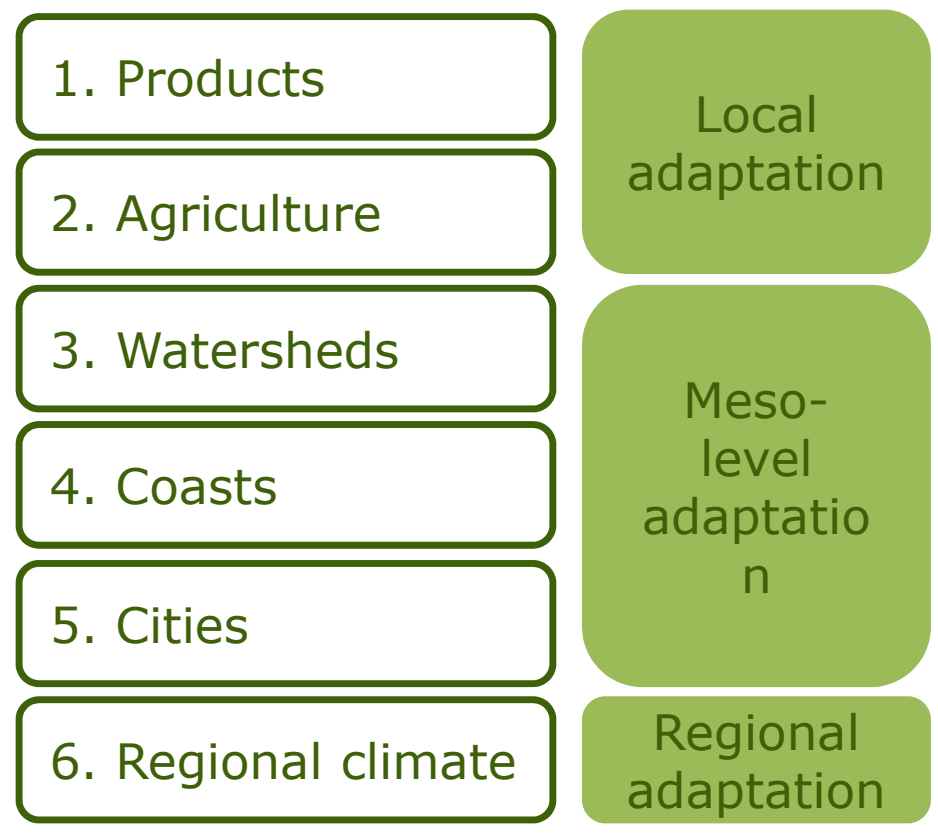

More evidence

More knowledge gaps and controversies

- The knowledge (e.g. on forest hydrology) should be revisited with a climate change adaptation lens

- Uncertainties on some benefits of EBA to adaptation but need to consider co-benefits (biodiversity, climate change mitigation) 


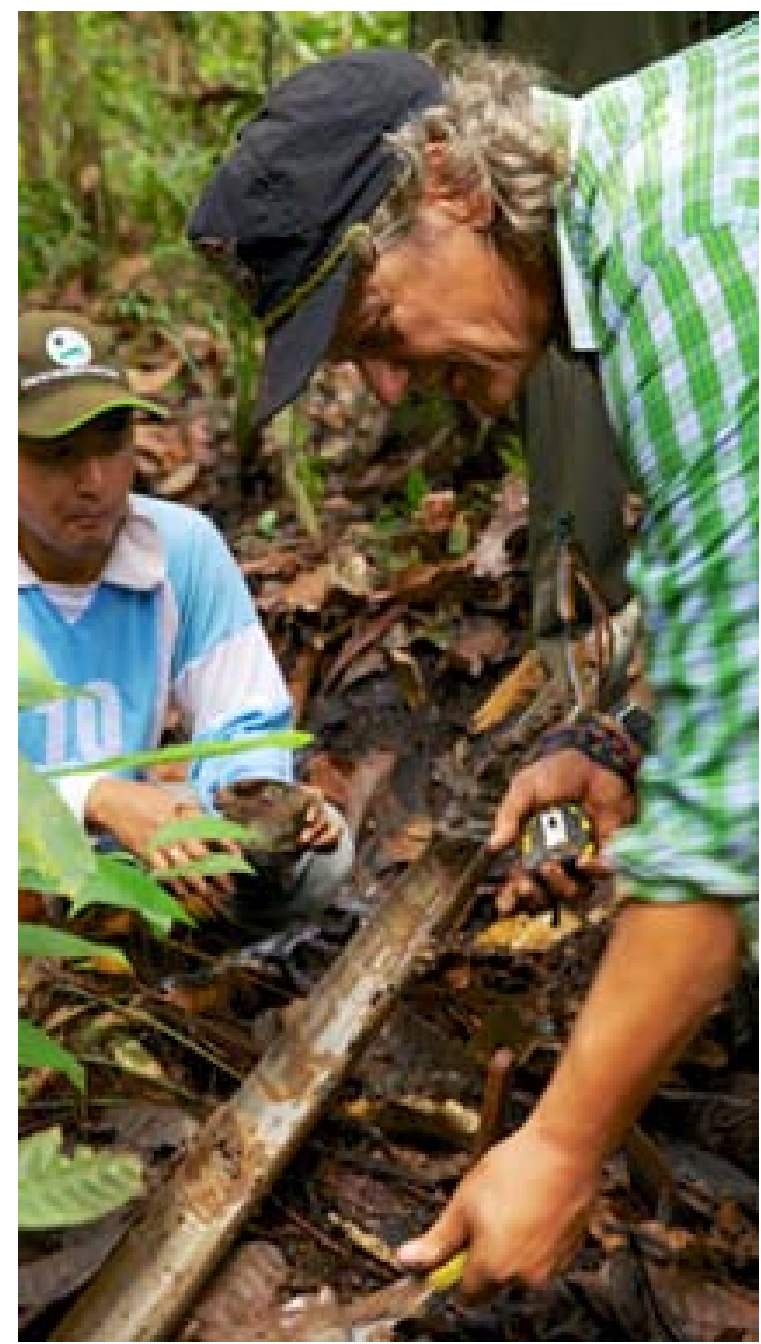

\section{Part 2. Discussing the opportunities and challenges of EBA}

- The question:

- Is EBA just theoretical? Is it applied?

- What are the opportunities?

- What are the challenges?

- Discussion with the participants:

- Do you know concrete examples of EBA interventions? What make them interesting? What have been the challenges in implementing them? 


\section{Examples of EBA in adaptation policies}

- Analysis of 44 NAPAs (National Adaptation Programmes of Action) and their 468 projects

- To what extent are ecosystem services considered?

- $68 \%$ of NAPAs have at least one reference to ecosystem services

- Mainly from forests and coastal or marine ecosystems

- $22 \%$ of the projects include ecosystem services for social adaptation or well-being

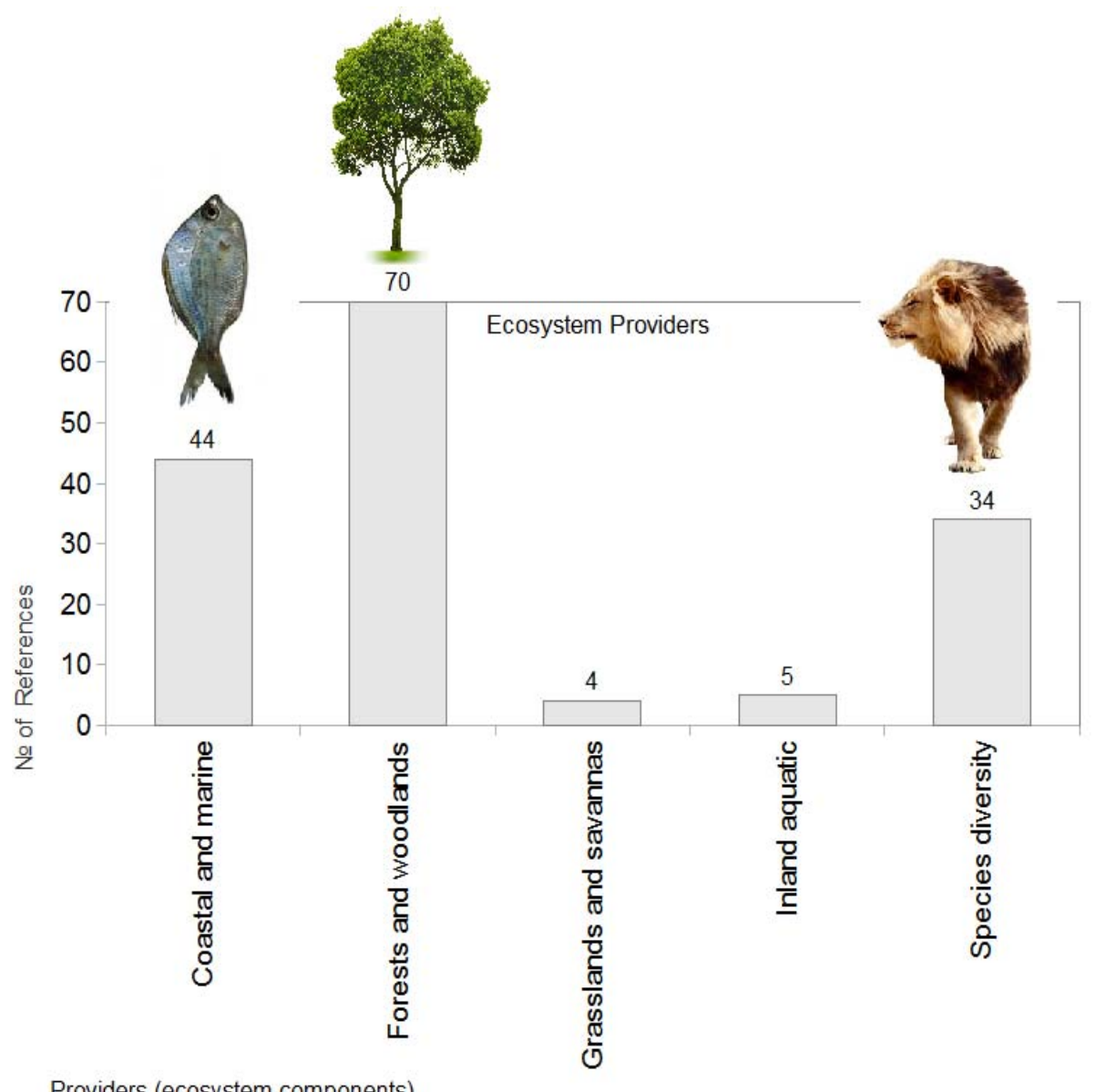




\section{Opportunities}

- Multiple benefits across landscapes

- Biodiversity conservation and enhancement

- Contribution to mitigation

- Conserving ecosystems for adaptation also conserves carbon

- EBA projects may also tap carbon financing

- No-regret and flexible measures

- Cost-effectiveness

- TEEB (The Economics of Ecosystems and Biodiversity): maintaining nature's capacity to buffer the impacts of climate change on people is often less costly than having to replace lost ecosystem functions through the use of heavy infrastructure or technology.

- Multiple benefits across sectors

- But can be also a challenge of cross-sectoral coordination

- Example: Forestry sector, water agencies, etc. 


\section{Conserving ecosystems for their 'adaptation services' can contribute to conserving its 'mitigation service'}

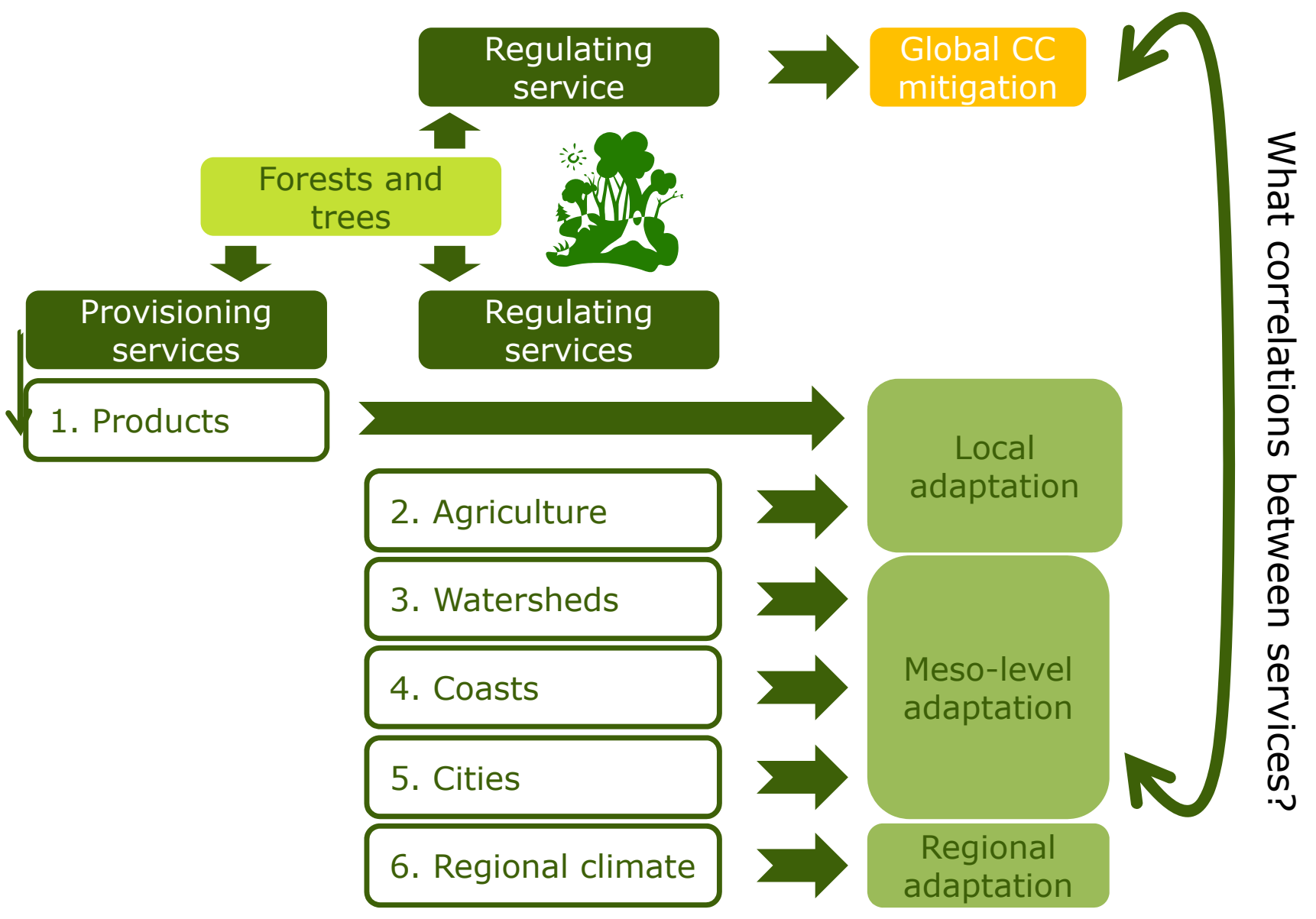




\section{Challenges}

- How to deal with complexity and diversity?

- Feedback loops, diversity of stakeholders, sectors, scales, contexts

- How to adapt ecosystem management to climate change or changes in social vulnerability?

- Adaptive management

- How to characterize ecosystem?

- E.g. what mangrove width, height, or species for protection?

- How to balance trade-offs?

- Short- vs. long-term needs (e.g. aquaculture vs. mangroves in coasts)

- Trade-offs between different ecosystem services

- How to finance?

- Transfers from beneficiaries of services to ecosystem managers

- Carbon funding 


\section{Vegetation barrier for storm protection}

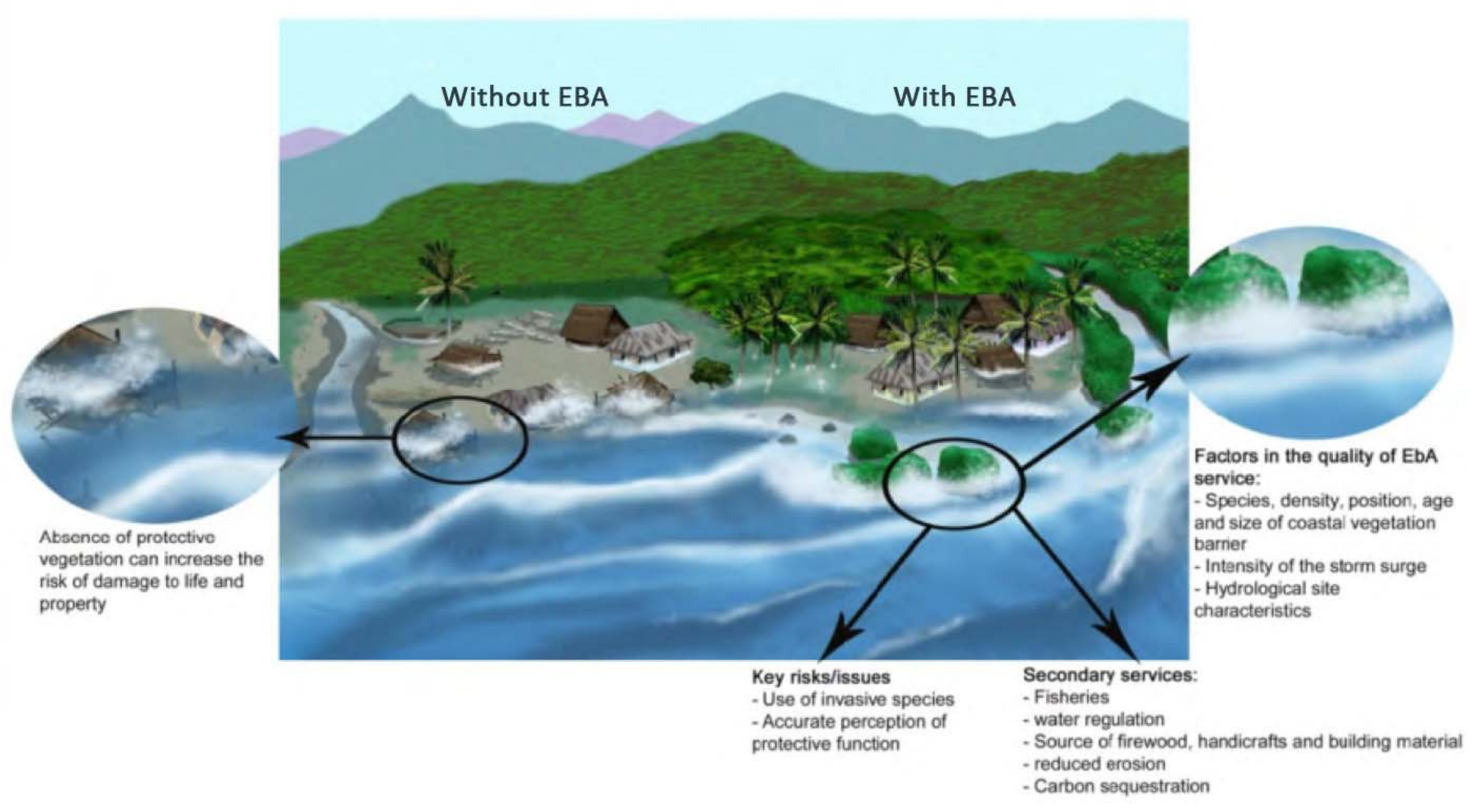




\section{References}

Badola R and Hussain SA. 2005. Valuing ecosystem functions: An empirical study on the storm protection function of Bhitarkanika mangrove ecosystem, India. Environmental Conservation 32:85-92.

[CBD] Convention on Biological Diversity. 2009. Connecting biodiversity and climate change mitigation and adaptation: Report of the second ad hoc technical expert group on biodiversity and climate change. Montreal, Canada: Secretariat of the Convention on Biological Diversity.

Das S and Vincent JR. 2009. Mangroves protected villages and reduced death toll during Indian super cyclone. Proceedings of the National Academy of Sciences of the United States of America 106: 7357-60.

Ellison D, Futter MN and Bishop K. 2012. On the forest cover-water yield debate: From demand-to supply-side thinking. Global Change Biology 18:806-20.

Garrity DP, Akinnifesi FK, Ajayi OC, Weldesemayat SG, Mowo JG, Kalinganire A, Larwanou M and Bayala J. 2010. Evergreen Agriculture: A robust approach to sustainable food security in Africa. Food Security 2:197-214.

Gill SE, Handley JF, Ennos AR and Pauleit S. 2007. Adapting cities for climate change: The role of the green infrastructure. Built Environment 33:115-33.

[IUCN] International Union for Conservation of Nature. 2009. Ecosystem-based adaptation (EbA): policy briefing. Fifth session of the UNFCCC ad hoc working group on long-term cooperative action under the convention (AWG-LCA), 29 March to 8 April 2009. Gland, Switzerland: IUCN. 


\section{References}

Liswanti N, Sheil D, Basuki I, Padmanaba M and Mulcahy G. 2011. Falling back on forests: How forest-dwelling people cope with catastrophe in a changing landscape. International Forestry Review 13:442-55.

Locatelli B. 2011. Synergies between adaptation and mitigation in a nutshell. Bogor, Indonesia: CIFOR. http://goo.gl/yQQQZ

Locatelli B, Kanninen M, Brockhaus M, Colfer CJP, Murdiyarso D and Santoso H. 2008. Facing an uncertain future: How forest and people can adapt to climate change. Bogor, Indonesia: CIFOR.

Locatelli B and Vignola R. 2009 Managing watershed services of tropical forests and plantations: Can meta-analyses help? Forest Ecology and Management 258:1864-70.

McSweeney K. 2005. Natural insurance, forest access, and compounded misfortune: forest resources in smallholder coping strategies before and after Hurricane Mitch, eastern Honduras. World Development 33:1453-71.

Makarieva A and Gorshkov V. 2007. Biotic pump of atmospheric moisture as driver of the hydrological cycle on land. Hydrology and Earth System Sciences 11:1013-33.

Pattanayak SK and Kramer R. 2001. Worth of watersheds: A producer surplus approach for valuing drought mitigation in Eastern Indonesia. Environment and Development Economics 6:123-46.

Pramova E, Locatelli B, Brockhaus M and Fohlmeister S. 2012. Ecosystem services in the National Adaptation Programmes of Action. Climate Policy 12:393-409.

Pramova E, Locatelli B, Djoudi $\mathrm{H}$ and Somorin OA. 2012. Forests and trees for social adaptation to climate variability and change. Climate Change 3:581-96. 


\section{References}

Robledo C, Fischler M and Patino A. 2004. Increasing the resilience of hillside communities in Bolivia: Has vulnerability to climate change been reduced as a result of previous sustainable development cooperation? Mountain Research and Development 24:14-18.

Schwendenmann I, Veldkamp E, Moser G, Hölscher D, Köhler M, Clough Y, Anas I, Djajakirana G, Erasmi S and Hertel D. 2010. Effects of an experimental drought on the functioning of a cacao agroforestry system, Sulawesi, Indonesia. Global Change Biology 16:1515-30.

Solecki WD, Rosenzweig C, Parshall L, Pope G, Clark M, Cox J and Wiencke M. 2005. Mitigation of the heat island effect in urban New Jersey. Global Environmental Change Part B: Environmental Hazards 6:39-49.

Tri NH, Adger WN and Kelly PM. 1998. Natural resource management in mitigating climate impacts: The example of mangrove restoration in Vietnam. Global Environmental Change 8:49-61.

Vignola R, Locatelli B, Martinez C and Imbach P. 2009. Ecosystem-based adaptation to climate change: What role for policy-makers, society and scientists? Mitigation and Adaptation Strategies for Global Change 14:691-96.

Wertz-Kanounnikoff S, Locatelli B, Wunder S and Brockhaus M. 2011. Ecosystem-based adaptation to climate change: What scope for payments for environmental services? Climate and Development 3:143-58. 


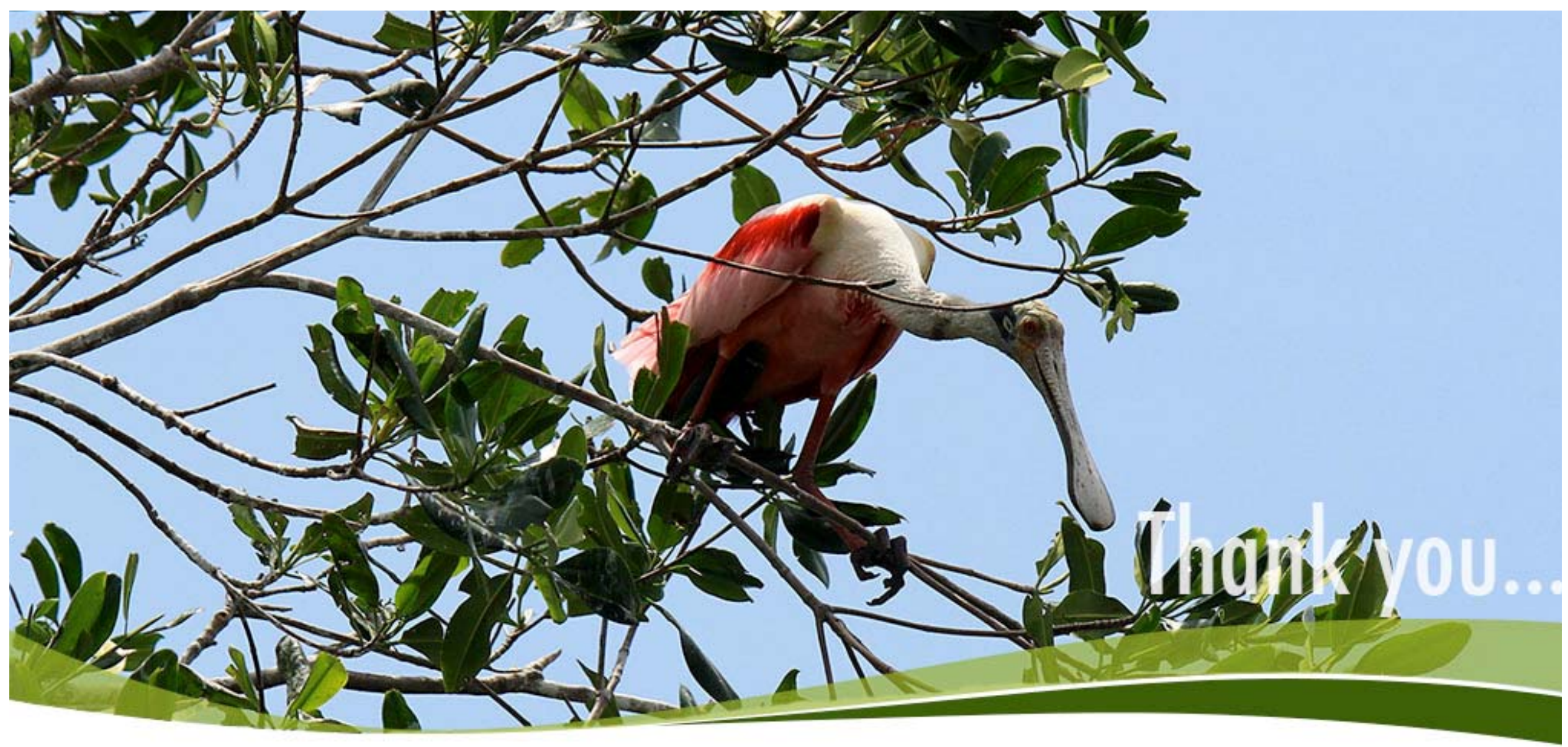

The Sustainable Wetlands Adaptation and Mitigation Program (SWAMP) is a collaborative effort by CIFOR, the USDA Forest Service, and the Oregon State University with support from USAID.

How to cite this file

Locatelli B. and Pramova E. 2015. Ecosystem-based adaptation[PowerPoint presentation]. In: SWAMP toolbox: Theme B section B1. Retrieved from

\section{Photo credit}

Aulia Erlangga/CIFOR, Bruno Locatelli/CIFOR, Daniel Murdiyarso/CIFOR, Dita Alangkara/CIFOR, James Maiden/CIFOR, Nanang Sujana/CIFOR, Neil Palmer/CIAT, Ramadian Bachtiar/CIFOR, Yayan Indriatmoko/CIFOR.

$$
\text { ; }
$$

